\title{
KEANEKARAGAMAN JENIS AMFIBI (ORDO ANURA) PADA BEBERAPA TIPE HABITAT DI YOUTH CAMP DESA HURUN KECAMATAN PADANG CERMIN KABUPATEN PESAWARAN \\ (AMPHIBIANS DIVERSITY (ORDO ANURA) ON SEVERAL HABITAT TYPES YOUTH CAMP AT HURUN VILLAGE PADANG CERMIN SUB DISTRICT PESAWARAN)
}

\author{
Yudi Safril Ariza, Bainah Sari Dewi, dan Arief Darmawan \\ Mahasiswa Jurusan Kehutanan, Fakultas Pertanian, Universitas Lampung \\ Jl. Prof. Dr. Sumantri Brojonegoro No.1 Bandar Lampung, 35145 \\ E-mail : yudisafril01@gmail.com
}

\begin{abstract}
ABSTRAK
Amfibi merupakan salah satu komponen penyusun ekosistem, baik secara ekologis maupun ekonomis. Penelitian mengenai amfibi di Indonesia masih sangat terbatas. Pulau Sumatera sebagai salah satu pulau besar, tetapi belum banyak dilakukan penelitian mengenai amfibi. Penelitian ini bertujuan untuk membandingkan keanekaragaman jenis amfibi (Ordo Anura) yang aktif pada malam hari yang terdapat di Youth Camp berdasarkan tipe habitat. Penelitian dilakukan pada tiga tipe habitat yang berbeda, terdiri dari: (1) hutan, (2) perkebunan, dan (3) sungai. Metode yang digunakan dalam pengambilan data amfibi adalah Visual Encounter Survey dengan metode jalur transek. Identifikasi dilakukan dengan buku panduan turun lapang. Analisis data dilakukan secara deskriptif serta statistik untuk menghitung indeks keanekaragaman jenis Shannon-Wiener dan indeks kemerataan. Di Youth Camp ditemukan sebanyak 105 individu terdiri dari 15 jenis amfibi dan 5 famili: Bufonidae 3 jenis, Megophrydae 1 jenis, Microhylidae 2 jenis, Ranidae 7 jenis, dan Rhacophoridae 2 jenis. Pada habitat hutan ditemukan 8 spesies, habitat perkebunan 5 spesies, dan habitat sungai 7 spesies. Nilai keanekaragaman amfibi di tiga habitat dikategorikan sedang dan nilai kemerataan di tiga habitat yaitu, habitat hutan $\mathrm{J}=0,695$, habitat perkebunan $\mathrm{J}=0,578$ dan habitat sungai $\mathrm{J}=0,477$.
\end{abstract}

Kata kunci : amfibi, Hanura, keanekaragaman, Youth Camp

\section{ABSTRACT}

Amphibian is one of important ecosystem component, both ecologicaly and economicaly. Research about amphibian in Indonesia is still very limited. In Sumatra, one of Indonesia's largest islands, there hasn't been much attention on research about amphibians. This study aimed to compari the diversity of nocturnal amphibians (Ordo Anura) about at Youth Camp on habitat types. This study was implemented at three different types of habitat, (1) forest, (2) plantations, and (3) rivers. The data was collected by visual encounter survey using line transect method. Identification was book using identification guidebook. The data was analyzed descriptively as well as statistically to calculate species richness and shannonwiener biodiversity index and evenness index. There were 105 individuals comprising 15 species of amphibians and 5 families: Bufonidae 3 species, Megophrydae 1 species, Microhylidae 2 species, Ranidae 7 species, and Rhacophoridae 2 species. Forest habitat found 8 species, plantation habitat 5 species, and river habitat 7 species. The biodiversity index of amphibian at three habitat being categori and evenness index are forest habitat $J=0,695$, plantation habitat $J=0,578$ and river habitat $J=0,477$.

Key words : amphibians, diversity, Hanura, Youth Camp 


\section{PENDAHULUAN}

Amfibi merupakan salah satu komponen penyusun ekosistem yang memiliki peranan sangat penting, baik secara ekologis maupun ekonomis. Secara ekologis, amfibi berperan sebagai pemangsa konsumen primer seperti serangga atau hewan invertebrata lainnya (Iskandar,1998) serta dapat digunakan sebagai bioindikator kondisi lingkungan (Stebbins dan Cohen, 1997). Secara ekonomis amfibi dapat dimanfaatkan sebagai sumber protein hewani, hewan percobaan, hewan peliharaan dan bahan obat-obatan (Stebbins dan Cohen, 1997).

Habitat utama amfibi adalah hutan primer, hutan sekunder, hutan rawa, sungai besar, sungai sedang, anak sungai, kolam dan danau (Mistar 2003). Umumnya amfibi dijumpai pada malam hari atau pada musim penghujan. Iskandar (1998) menyatakan bahwa amfibi selalu hidup berasosiasi dengan air sesuai namanya yaitu hidup pada dua alam (di air dan di darat). Selanjutnya dijelaskan bahwa sebagian besar amfibi didapatkan hidup di kawasan hutan karena di samping membutuhkan air juga membutuhkan kelembaban yang cukup tinggi (75-85\%) untuk melindungi tubuh dari kekeringan.

Penelitian tentang amfibi di Indonesia kurang mendapat perhatian dan terbatas. Pulau Sumatera sebagai salah satu pulau besar, tetapi belum banyak dilakukan penelitian mengenai amfibi. Hal ini antara lain karena kurang dikenalnya hewan ini dimasyarakat umum maupun di kalangan peneliti, seperti yang ditengarai oleh Iskandar dan Erdelen (2006). Adanya persepsi negatif bahwa katak beracun atau menjijikkan (Kusrini, 2003) membuat amfibi dijauhi oleh masyarakat. Salah satu catatan mengenai diabaikannya amfibi secara politis adalah tidak adanya amfibi di Indonesia yang masuk ke dalam daftar satwa liar yang dilindungi oleh undang-undang. Oleh karena itu, tidaklah mengherankan jika lokasi-lokasi penting bagi spesies atau komunitas amfibi menjadi rusak atau berubah karena tidak ada yang tahu mengenai hewan yang hidup di dalamnya. Maka dari itu untuk mengenalkan amfibi kepada masyarakat harus dibutuhkan data keanekaragaman jenis amfibi pada berbagai tipe habitat di Youth Camp sebagai upaya konservasi agar tetap mempertahankan populasi, kondisi lingkungan dan habitat amfibi.

Penelitian ini dilakukan untuk membandingkan keanekaragaman jenis amfibi (Ordo Anura) yang aktif di malam hari yang terdapat di Youth Camp berdasarkan tipe habitat (hutan, perkebunan dan sungai).

\section{METODE PENELITIAN}

Penelitian dilaksanakan pada bulan Maret sampai April 2012. Pengamatan dan pengambilan data dilakukan pada malam hari mulai dari pukul 18.00 WIB sampai dengan 20.00 WIB. Penelitian ini dilakukan di Youth Camp Tahura WAR, peta lokasi penelitian dapat dilihat pada Gambar 1. Pembagian tipe habitat di Youth Camp terdiri dari habitat hutan, habitat perkebunan dan habitat sungai. Pembagian habitat ini bertujuan untuk mempermudah dalam penemuan spesies amfibi, karena amfibi memiliki karakteristik habitat di akuatik dan teresterial.

Alat dan bahan yang digunakan dalam penelitian adalah sebagai berikut:

1) Alat tulis untuk mencatat hasil pengamatan.

2) Kantong plastik, wadah spesimen.

3) Kamera untuk alat dokumentasi.

4) Jam tangan untuk mengukur waktu penelitian.

5) Headlamp dan Senter, untuk alat penerangan.

6) Buku panduan turun lapang untuk mengidentifikasi spesies.

7) Timbangan digital, untuk mengukur berat spesies (g). 
8) Tally sheet, untuk pengumpulan data morfometri spesies.

9) Higrotermometer untuk mengukur kelembapan udara $(\%)$ dan suhu lingkungan $\left({ }^{\circ} \mathrm{C}\right)$.

10) Global Positioning System (GPS) untuk pengambilan titik koordinat.

11) Kaliper untuk mengukur panjang sampel (mm).

12) Karet jepang warna merah untuk penandaan spesies yang ditemukan (Tagging). Jenis data pendukung yaitu:

1. Data Primer

Data primer meliputi jenis-jenis amfibi yang dijumpai di kawasan pengamatan dan perjumpaan dengan amfibi serta data habitat meliputi: tanggal dan waktu pengambilan data, nama lokasi, substrat/lingkungan tempat ditemukan, tipe vegetasi, ketinggian, suhu, cuaca, dan kelembaban udara (Heyer dkk. 1994).

2. Data Sekunder

Data sekunder meliputi studi literatur yang mendukung penelitian, seperti:

a. Keadaan umum lokasi penelitian meliputi letak dan kondisi fisik.

b. Literatur yang berhubungan dengan pe-nelitian ini serta literatur penunjang lainnya sebagai bahan referensi.

Metode yang digunakan dalam penelitian ini adalah metode VES (Visual Encounter Survey/Survei Perjumpaan Visual) dengan jalur/transek dan metode identifikasi. Metode Jalur/Transek adalah metode pengamatan dengan cara berjalan perlahan terus menerus dan mencatat semua kontak disepanjang kedua sisi jalur perjalanannya sedangkan metode identifikasi adalah metode untuk menentukan spesies amfibi yang sudah tertangkap dengan menggunakan buku panduan amfibi. Penelitian ini menggunakan jalur transek dengan panjang $1 \mathrm{KM}$, panjang transek ini berlaku pada masing-masing habitat, sedangkan survei lokasi dilakukan pada sore hari sebelum pengamatan.

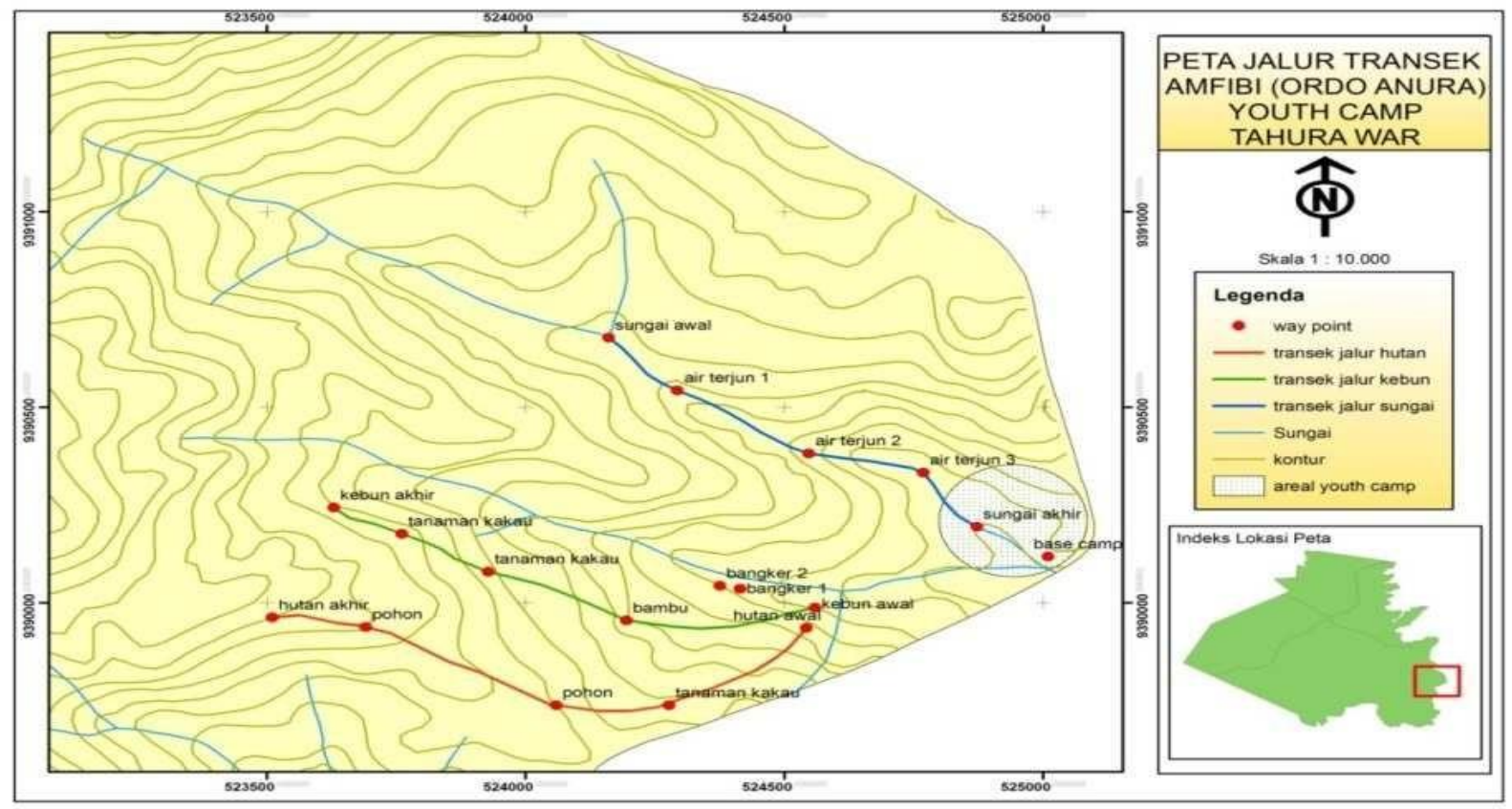

Gambar 1. Peta lokasi penelitian dan jalur pengamatan pada masing-masing habitat di Youth Camp, (Sumber UPTD Tahura WAR 2009).

Adapun cara kerja penelitian ini adalah sebagai berikut:

1) Melakukan observasi pendahuluan ke lokasi penelitian.

2) Menentukan titik hitung disepanjang transek dan membuat batas daerah penelitian.

3) Mempersiapkan alat dan bahan yang akan digunakan dalam penelitian. 
4) Mengukur komponen habitat antara suhu relatif, kelembaban relatif, vegetasi, dan cuaca.

5) Melakukan proses pengambilan sampel penelitian pada setiap titik dengan cara manual.

6) Memasukkan hewan sampel yang ditemukan ke dalam plastik yang telah diberi label.

7) Menghitung jumlah spesies sampel yang didapat.

8) Mencatat data morfometri dan data pendukung lainnya.

9) Mendokumentasikan hewan sampel yang ditemukan.

10) Mengidentifikasikan hewan sampel yang ditemukan dengan buku identifikasi sesuai dengan literatur buku A Field Guide to the Frogs of Borneo (Inger dan Stuebing, 2005) dan Panduan Lapangan Amfibi Jawa dan Bali (Iskandar, 1998).

Analisis data penelitian terdiri atas:

1. Analisis Keanekaragaman Amfibi

Untuk mengetahui keanekaragaman jenis dihitung dengan menggunakan indeks keanekaragaman Shannon-Wienner (Odum, 1971 dikuti oleh Fachrul, 2007), dengan rumus sebagai berikut:

$H^{\prime}=-\sum P i \ln (P i)$, dimana $P i=(n i / N)$

Keterangan:

$H^{\prime}=$ Indeks keanekaragaman Shannon-Wienner

$n i=$ Jumlah individu jenis ke-i

$N=$ Jumlah individu seluruh jenis

Kriteria nilai indeks keanekaragaman Shannon-Wiener $\left(H^{\prime}\right)$ adalah sebagai berikut:

$H^{\prime}<1 \quad$ : keanekaragaman rendah

$1<H^{\prime} \leq 3$ : keanekaragaman sedang

$\mathrm{H}^{\prime}>3$ : keanekaragaman tinggi

2. Indeks Kemerataan

Indeks kemerataan digunakan untuk mengetahui kemerataan setiap spesies dalam setiap komunitas yang dijumpai, dengan mengunakan rumus:

$J=H^{\prime} / H$ max atau $J=-\sum P i \ln (P i) / \ln (S)$

Keterangan:

$J=$ Indeks kesamarataan

$S=$ Jumlah spesies

Rumus ini digunakan karena nilai $H^{\prime}$ sudah diperoleh sebelumnya sehingga lebih mudah dalam perhitungannya. Kriteria indeks kemerataan $(J)$ menurut Daget (1976) dikutip oleh Solahudin (2003) adalah sebagai berikut:

$0<J \leq 0,5 \quad$ : Komunitas tertekan

$0,5<J \leq 0,75$ : Komunitas labil

$0,75<J \leq 1 \quad$ : Komunitas stabil

3. Analisis Kesamaan Spesies Antar Habitat

Indeks kesamaan (Similarity index) diperlukan untuk mengetahui tingkat kesamaan komposisi spesies antar dua habitat, dihitung dengan menggunakan rumus (Odum, 1993 dikutip oleh Indriyanto, 2006).

IS $=2 \mathrm{C} /(\mathrm{A}+\mathrm{B})$

Keterangan:

$\mathrm{C}=$ jumlah spesies yang sama pada kedua komunitas

$\mathrm{A}=$ jumlah spesies yang hanya dijumpai pada lokasi 1

$\mathrm{B}=$ jumlah spesies yang hanya dijumpai pada lokasi 2

4. Analisis Deskriptif

Analisis deskriptif digunakan dalam penggunaan habitat dan vegetasi oleh amfibi, ditabulasikan dan diuraikan secara deskriptif berdasarkan hasil pengamatan yang dilakukan. 


\section{HASIL DAN PEMBAHASAN}

Berdasarkan hasil pengamatan, di Youth Camp ditemukan 105 individu (15 spesies) amfibi Ordo Anura yang termasuk dalam 5 Famili yang berhasil ditangkap dan diidentifikasi. Spesies amfibi tersebar di tiga habitat yaitu, habitat hutan 8 spesies, habitat perkebunan 5 spesies dan habitat sungai dengan jumlah 7 spesies, untuk hasil spesies yang ditemukan selama penelitian di tiga habitat dapat dilihat pada Tabel 1.

Tabel 1. Jenis-jenis amfibi (Ordo Anura) yang berhasil ditangkap dan diidentifikasi pada berbagai tipe habitat di Youth Camp.

\begin{tabular}{|c|c|c|c|c|c|c|}
\hline No & Famili & Spesies & Sungai & $\begin{array}{l}\text { Lokasi } \\
\text { Hutan }\end{array}$ & Perkebunan & $\begin{array}{c}\text { Jumlah } \\
\text { Total }\end{array}$ \\
\hline \multirow[t]{3}{*}{1} & Bufonidae & Ansonia leptopus & 1 & 0 & 0 & 1 \\
\hline & & Bufo melanostictus & 0 & 7 & 0 & 7 \\
\hline & & Ingerophrynus divergens & 1 & 0 & 0 & 1 \\
\hline 2 & Megophryidae & Megophrys nasuta & 0 & 1 & 2 & 3 \\
\hline \multirow[t]{2}{*}{3} & Microhylidae & Microphyla annectens & 0 & 3 & 3 & 6 \\
\hline & & Microhyla butleri & 0 & 2 & 2 & 4 \\
\hline \multirow[t]{7}{*}{4} & Ranidae & Fejervarya limnocharis & 2 & 4 & 0 & 6 \\
\hline & & Limnonectes blythii & 3 & 0 & 0 & 3 \\
\hline & & Limnonectes malesianus & 0 & 0 & 2 & 2 \\
\hline & & Rana chalconota & 9 & 0 & 0 & 9 \\
\hline & & Rana erythraea & 16 & 0 & 0 & 16 \\
\hline & & Rana hosii & 38 & 0 & 0 & 38 \\
\hline & & Rana nicobariensis & 0 & 2 & 0 & 2 \\
\hline \multirow[t]{3}{*}{5} & Rhacophoridae & Polypedates leucomystax & 0 & 1 & 4 & 5 \\
\hline & & Polypedates macrotis & 0 & 2 & 0 & 2 \\
\hline & Jumlah Total & 15 jenis & 70 & 22 & 13 & 105 \\
\hline
\end{tabular}

Indeks keanekaragaman spesies amfibi pada beberapa habitat di Youth Camp Desa Hurun dapat dilihat pada Tabel 2. Berdasarkan hasil penelitian diketahui indeks keanekaragaman pada ketiga habitat tergolong keanekaragaman sedang $\left(1>\mathrm{H}^{\prime}<3\right)$, dengan nilai indeks keanekaragaman pada, habitat hutan sebesar 1,881, habitat perkebunan sebesar 1,565 dan habitat sungai sebesar 1,291. Selain itu untuk keanekaragaman jenis amfibi di Youth Camp dikategorikan sedang yaitu dengan nilai indeks keanekaragaman $\mathrm{H}^{\prime}=2.160$. Nilai indeks kemerataan spesies dapat menggambarkan kestabilan suatu komunitas. Menurut Daget (1976) dikutip oleh Solahudin (2003) bila angka nilai kemerataan $0<J \leq$ 0,5 maka dikatakan komunitas tertekan, nilai kesemerataan $0,5<J \leq 0,75$ dikatakan komunitas stabil dan bila nilai kesemerataan $0,75<J \leq 1$ maka dikatakan komunitas stabil. Nilai indeks kemerataan pada berbagai tipe habitat di Youth Camp dapat dilihat pada Tabel 2.

Tabel 2. Indeks keanekaragaman Shannon-Wiener (H') dan indeks kemerataan (J) spesies amfibi yang ditemukan di Youth Camp.

\begin{tabular}{ccccc}
\hline No & Youth Camp & $\begin{array}{c}\text { Jumlah } \\
\text { Spesies }\end{array}$ & $\begin{array}{c}\text { Indeks } \\
\text { Keanekaragaman (H') }\end{array}$ & $\begin{array}{c}\text { Indeks } \\
\text { Kemerataan }(\mathbf{J})\end{array}$ \\
\hline 1 & Sungai & 70 & 1,291 & 0,477 \\
2 & Hutan & 22 & 1,881 & 0,695 \\
3 & Perkebunan & 13 & 1,565 & 0,578 \\
\hline
\end{tabular}


Hasil penelitian nilai kemerataan terdapat dua kategori yaitu komunitas tertekan dan komunitas labil. Komunitas tertekan terdapat di habitat sungai $(\mathrm{J}=0,477)$, sedangkan kategori komunitas labil terdapat di habitat hutan $(\mathrm{J}=0,695)$ dan perkebunan $(\mathrm{J}=0,578)$.

Kesamaan spesies amfibi antar habitat di Youth Camp dapat dilihat pada Tabel 3. Nilai indeks kesamaan pada beberapa habitat di Youth Camp semuanya memiliki nilai mendekati angka 1. Nilai indeks kesamaan yang paling rendah terdapat antara habitat sungai dengan hutan dengan nilai 0,133, nilai indeks kesamaan yang paling tinggi terdapat antara habitat habitat hutan dengan perkebunan dengan nilai 0,615 spesies yang sama pada kedua habitat ini ada 4 spesies (Megophrys nasuta, Microhyla annectens, Microhyla butleri dan Polypedates leucomystax). Sedangkan untuk perbandingan indeks kesamaan yang berhasil adalah antara habitat sungai dengan perkebunan dengan tidak adanya spesies yang sama.

Jumlah spesies amfibi yang berhasil ditemukan pada seluruh lokasi penelitian di Youth Camp lebih tinggi dibandingkan dengan penelitian yang dilakukan sebelumnya (Sartono,2007) yang menghasilkan 4 Famili terdiri dari 10 spesies. Perbandingan hasil penelitian dapat dilihat pada Tabel 4 di bawah ini.

Penelitian yang dilakukan penulis terdapat penambahan 1 Famili dan 8 spesies amfibi yang sebelumnya tidak ditemukan oleh Sartono (2007) yaitu Megophryidae, Megophrys nasuta, Ansonia leptopus, Ingerophrynus divergens, Microhyla butleri, Limnonectes blythii, Limnonectes malesianus, Rana erythraea dan Polypedates leucomystax. Sedangkan ada 3 spesies yang tidak ditemukan dari hasil penelitian Sartono (2007) pada penelitian yang dilakukan penulis adalah Limnonectes macrodon, Bufo quadriporcatus dan Pelophryne brevipes. Tetapi untuk jumlah total keseluruhan individu amfibi yang berhasil ditemukan hasil tahun ini mengalami penurunan, tahun ini ditemukan 105 individu sedangkan untuk penelitian Sartono (2007) lebih besar yaitu 118 individu.

Perbedaan penemuan ini terjadi dikarenakan pembagian habitat, penulis melakukan di tiga habitat yang lebih sesuai dengan karakteristik habitat dari spesies amfibi sedangkan pada penelitian Sartono (2007) dilakukan pada 6 habitat yaitu, area kolam Abah Bewok, genangan air di belakang Gedung Serba Guna (GSG) Youth Camp, genangan air dekat bendungan, di belakang bangker penampungan air, di sekitar Camp, di jalan-jalan di bawah tegakan pohon. Sedangkan waktu pengamatan juga berbeda, pada penelitian Sartono (2007) pengamatan dilakukan pada pagi hari dan malam hari sedangkan penulis hanya pada malam hari saja dan usaha dalam pencarian akan sangat menentukan penemuan spesies amfibi ketika penelitian.

Berdasarkan hasil pengukuran di lapangan diperoleh suhu relatif yang berkisar antara $24-28^{\circ} \mathrm{C}$, sedangkan kelembaban relatif berkisar antara $81-98 \%$. Kondisi cuaca saat pengamatan pada umumnya adalah cerah (cerah cahaya bulan dan bintang) yang memudahkan dalam pengamatan sehingga perjumpaan lebih sering. Menurut Susanto (1999) dikutip oleh Yuliana (2000), bahwa secara umum katak bisa hidup di air yang suhunya berkisar antara $2-35^{\circ} \mathrm{C}$ sesuai dengan habitatnya, selain itu amfibi membutuhkan kelembaban yang cukup untuk melindungi diri dari kekeringan pada kulitnya (Iskandar 1998). Hal ini menunjukkan bahwa cuaca, suhu dan kelembaban seperti di Youth Camp katak masih dapat melaksanakan aktivitasnya. Data pengamatan keseluruhan dapat dilihat pada Tabel 5. Selain itu menurut Yuliana (2000), suhu udara berpengaruh secara nyata terhadap perkembangan dan pertumbuhan amfibi, serta seringkali mengatur siklus perilaku dan reproduksi. Amfibi merupakan jenis satwa yang poikiloterm, tidak dapat mengatur suhu tubuh sendiri sehingga suhu tubuhnya sangat tergantung pada kondisi lingkungannya. 
Tabel 3. Indeks kesamaan (Similarity Index) pada beberapa tipe habitat.

\begin{tabular}{|c|c|c|c|}
\hline Habitat & HS & HH & HP \\
\hline HS & - & 0,133 & 0 \\
\hline HH & & & 0,615 \\
\hline$H P$ & & & - \\
\hline
\end{tabular}

Keterangan:

HS : Habitat Sungai

HH : Habitat Hutan

HP : Habitat Perkebunan

Tabel 4. Perbandingan hasil penelitian di Youth Camp antara Ariza, Dewi dan Arief, 2012 dengan Sartono, 2007.

\begin{tabular}{|c|c|c|c|c|}
\hline \multirow[b]{2}{*}{ No } & \multirow{2}{*}{ Famili } & \multirow{2}{*}{ Spesies } & \multicolumn{2}{|c|}{ Hasil Penelitian } \\
\hline & & & Ariza et al, 2012 & Sartono, 2007 \\
\hline \multirow[t]{5}{*}{1} & Bufonidae & Ansonia leptopus & 1 & - \\
\hline & & Bufo melanostictus & 7 & 19 \\
\hline & & Bufo quadriporcatus & - & 5 \\
\hline & & Ingerophrynus divergens & 1 & - \\
\hline & & Pelophryne brevives & - & 9 \\
\hline 2 & Megophryidae & Megophrys nasuta & 3 & - \\
\hline \multirow[t]{2}{*}{3} & Microhylidae & Microphyla annectens & 6 & 2 \\
\hline & & Microhyla butleri & 4 & - \\
\hline \multirow[t]{8}{*}{4} & Ranidae & Fejervarya limnocharis & 6 & 3 \\
\hline & & Limnonectes blythii & 3 & - \\
\hline & & Limnonectes macradon & - & 11 \\
\hline & & Limnonectes malesianus & 2 & - \\
\hline & & Rana chalconota & 9 & 17 \\
\hline & & Rana erythraea & 16 & - \\
\hline & & Rana hosii & 38 & 4 \\
\hline & & Rana nicobariensis & 2 & 35 \\
\hline \multirow[t]{3}{*}{5} & Rhacophoridae & Polypedates leucomystax & 5 & 13 \\
\hline & & Polypedates macrotis & 2 & - \\
\hline & Jumlah Total & 18 jenis & 105 & 118 \\
\hline
\end{tabular}

Tabel 5. Keadaan suhu, kelembaban, ketinggian dan cuaca pada saat penelitian di Youth Camp.

\begin{tabular}{cccccc}
\hline No & Habitat dan Jalur & $\begin{array}{c}\text { Suhu } \\
\text { Relatif }\left({ }^{\circ} \mathbf{C}\right)\end{array}$ & $\begin{array}{c}\text { Kelembaban } \\
\text { Relatif }(\%)\end{array}$ & $\begin{array}{c}\text { Ketinggian } \\
(\mathbf{m d p l})\end{array}$ & Cuaca \\
\hline 1 & Sungai jalur 1 & $24,1-27,6$ & $81-98$ & $60-194$ & Cerah \\
2 & Hutan jalur 2 & $25,5-28,9$ & $81-90$ & $56-222$ & Cerah \\
3 & Perkebunan jalur 3 & $26,1-27,9$ & $81-98$ & $78-265$ & Cerah \\
\hline
\end{tabular}

Jika dilihat dari indeks keanekaragaman Shannon-Wienner yang paling tinggi dari tiga tipe habitat terdapat pada tipe habitat hutan dengan $H^{\prime}=1,881$, sedangkan yang paling rendah terdapat pada habitat sungai dengan $H^{\prime}=1,291$ dan untuk tiga tipe habitat memiliki nilai keanekaragaman jenis yang tergolong sedang. Menurut Odum (1971) dikutip oleh Fachrul (2007) menyatakan bahwa tingkat kelimpahan jenis yang tinggi ditunjukkan dengan nilai 
Indeks Shannon-Wienner H'>3, digolongkan sedang bila nilai indeks $1<\mathrm{H}^{\prime}<3$ dan rendah bila $\mathrm{H}^{\prime}<1$. Sedangkan pada penelitian sebelumnya oleh Sartono (2007) tidak menggunakan permbagian tipe habitat tetapi hanya melihat indeks keanekaragaman di Youth Camp dengan $H^{\prime}=2,048$ sedangkan pada penelitian penulis tidak jauh berbeda dengan $H^{\prime}=2,160$ yang diktegorikan sedang.

Indeks kemerataan dari tiga habitat dikategorikan labil dan tertekan. Kondisi stabil nilai kemerataan $0,5<J \leq 0,75$ sedangkan kondisi tertekan $0<J \leq 0,5$. Pada saat penelitian ada dua habitat yang dikategorikan labil yaitu di habitat perkebunan $(\mathrm{J}=0,578)$ dan hutan $(\mathrm{J}=0,695)$, ini terjadi dikarenakan tipe habitat diantara keduanya tidak jauh berbeda dan saling berdekatan. Habitat sungai dikategorikan tertekan $(\mathrm{J}=0,477)$ disebabkan pada lokasi habitat ini ada satu spesies yang mendominasi yaitu Rana hosii yang berjumlah 38 individu. Menurut Alikodra (2002), penyebaran satwa liar mempunyai pembatas-pembatas fisik seperti samudera dan gunung serta pembatas ekologis seperti batas tipe hutan dan jenis pesaing yang telah lebih lama beradaptasi di wilayah tersebut. Menurut Primack. dkk (1998) bahwa satwa liar akan semakin beranekaragam bila struktur habitatnya juga beraneka ragam.

Sedangkan pada saat penulis melakukan pembagian habitat tidak adanya pembatas diantara habitat dikarenakan lokasi penelitian masih berada dalam satu tempat serta jarak antar habitat yang berdekatan dan untuk struktur habitat tidak jauh berbeda, sehingga tingkat persebaran spesies amfibi banyak yang ditemukan pada berbagai habitat di Youth Camp.

Nilai indeks kesamaan yang paling rendah terdapat di habitat sungai dengan hutan dengan nilai 0,133 , spesies yang sama pada kedua habitat ini adalah Fejervarya limnocharis, hal ini karena pada kedua habitat memiliki kondisi yang berbeda sehingga memiliki komposisi spesies amfibi yang berbeda pula. Selain itu, spesies amfibi mempunyai karakteristik habitat yang berbeda sesuai dengan morfometri tubuh spesies amfibi. Nilai indeks kesamaan yang paling tinggi terdapat di habitat habitat hutan dengan perkebunan dengan nilai 0,615 spesies yang sama pada kedua habitat ini ada 4 spesies (Megophrys nasuta, Microhyla annectens, Microhyla butleri dan Polypedates leucomystax). Hal ini dikarenakan tipe kedua habitat memiliki kesamaan tanaman kakau (Theobroma cacao) yang mendominasi. Sedangkan untuk perbandingan indeks kesamaan yang berhasil adalah antara habitat sungai dengan perkebunan dengan tidak adanya spesies yang sama.

Perilaku yang sering ditemui saat pengamatan adalah aktivitas duduk. Sebagian besar amfibi mencari makan dengan strategi diam dan menunggu (Duellman dan Heatwole, 1998). Jenis- jenis yang paling sensitif ketika saat ditemukan adalah Genus Limnonectes antara lain Limnonectes blythii, dan Limnonectes malesianus. Katak jenis ini akan segera melompat ke sekitar atau menyelam ke dalam air ketika pengamat mendekat. Jenis-jenis lain yang juga segera melompat saat ditemukan adalah Ansonia leptopus, Fejervarya limnocharis, Rana nicobariensis, Microhyla anectens, Microhyla butleri dan Rana hosii. Jenis yang memiliki kaki yang relatif pendek, seperti famili Megophryidae hanya melakukan penyamaran dan bersembunyi di serasah dedaunan apabila tidak kita ganggu mereka tetap diposisinya (Iskandar, 1998). Selain itu juga dijumpai jenis-jenis yang sedang bersuara. Perilaku bersuara pada umumnya berhubungan dengan proses perkembangbiakan (Goin dan Goin 1971), jenis- jenis tersebut antara lain Ansonia leptopus, Rana erythraea, Rana picturata, Polypedates leucomystax, Rhacophorus nigropalmatus, Rhacophorus pardalis, dan Rhacophorus reinwardtii. Pada saat pengamatan Jenis Rana erythraea dan Rana hosii yang bersuara pada malam hari, sedangkan pada pengamatan hanya ditemukan satu jenis yang sedang melakukan perkawinan (amplexus) yaitu Famili Ranidae spesies Rana hosii. 


\section{SIMPULAN}

Selama pengamatan yang telah dilakukan dijumpai 105 individu spesies amfibi (Ordo Anura) terdiri dari 15 spesies yang termasuk ke dalam 5 famili. Kelima belas spesies tersebut di jumpai pada tiga habitat yang berbeda, habitat hutan 8 spesies dengan 22 individu, habitat perkebunan 5 spesies dengan 13 individu dan habitat sungai 7 spesies dengan 70 individu. Keanekaragaman pada ketiga habitat dikategorikan sedang, dengan nilai paling tinggi terdapat di habitat hutan $H^{\prime}=1,881$ dan keanekaragaman paling rendah terdapat di habitat sungai $H^{\prime}=1,291$.

\section{DAFTAR PUSTAKA}

Alikodra HS. 2002. Pengelolaan Satwaliar. Bogor: Yayasan Penerbit Fakultas Kehutanan. Duellman WE dan Heatwole H. 1998. Habitats and Adaptations. In: HG Cogger and RG.

Zweifel 1998. Encyclopedia of Reptiles and Amphibians. Second Edition. San Fransisco: Fog City Pr.

Fachrul MF. 2007. Metode Sampling Bioekologi. Buku. Jakarta: Bumi Aksara.

Goin CJ dan Goin OB. 1971. Introduction to Herpetology. Second Edition. San Francisco: Freeman.

Heyer WR, Donnelly MA, Diarmid RW, Hayek LC dan Foster MS.. 1994. Measuring and Monitoring Biological Diversity: Standard Method for Amphibians. Washington: Smithsonian Institution Pr.

Indriyanto. 2006. Ekologi Hutan. Buku. Jakarta: Bumi Aksara.

Inger RF dan Stuebing RB. 2005. A Field Guide to The Frogs of Borneo. Second Edition. Kota Kinabalu: Natural History Publications (Borneo).

Iskandar DT. 1998. Amfibi Jawa dan Bali - Seri Panduan Lapangan. Bogor: Puslitbang LIPI.

Iskandar DT dan Erdelen WR. 2006. Conservation of amphibians and reptiles in Indonesia: issues and problems. Amphib. Reptile Conserv. 4(1):60-93.

Kusrini MD. 2003. Predicting the impact of the frog leg trade in Indonesia: An ecological view of the indonesian frog leg trade, emphasizing Javanese edible frog species. Dalam: MD Kusrini, A Mardiastuti dan T Harvey 2003 Konservasi Amfibi dan Reptil di Indonesia. Bogor. Fakultas Kehutanan IPB. Hal. 27-44.

Mistar. 2003. Panduan Lapangan Amfibi Kawasan Ekosistem Leuser. The Gibbon Foundation dan PILI-NGO Movement. Bogor.

Primack RB, Supriatna J, Indrawan M dan Kramadibrata P. 1998. Biologi Konservasi. Buku. Yayasan Obor Indonesia. Jakarta.

Sartono L. 2007. Study keanekaragaman anura di Youth Camp Taman Hutan Raya (TAHURA) Wan Abdul Rachman, Lampung. Skripsi. Bandar Lampung: Universitas Lampung.

Solahudin AM. 2003. Keanekaragaman jenis burung air di Lebak Pampangn Kecamatan Pampangan Kabupaten Ogan Komering Ilir Sumatera Selatan. Skripsi. Universitas Lampung. Bandar Lampung.

Stebbins RC dan Cohen NW. 1997. A Natural History of Amphibians. New Jersey, Princeton Univ. Pr.

Yuliana S. 2000. Kenanekaragaman jenis amfibi (ordo anura) di kampus IPB Darmaga, Bogor. Skripsi. Bogor: Jurusan Konservasi Sumberdaya Hutan Fakultas Kehutanan, Institut Pertanian Bogor. 
Vol. 2 No. I. Januari 2014 (21-30)

Halaman ini sengaja dikosongkan 